\title{
Lo abyecto y lo inmirable: la muerte de la metáfora en Spiegelman, Scafati, Schrauwen y Shaw
}

\section{The abject and the unwatchable: death \\ of the metaphor in Spiegelman, Scafati, Schrauwen and Shaw}

\author{
Gustavo Faverón Patriau \\ Bowdoin College
}

Gustavo Faverón es profesor asociado de Bowdoin College, exprofesor visitante en Stanford. Autor de los libros académicos Rebeldes y Contra la alegoría, y de las novelas El anticuario y Vivir abajo, además de otros de carácter periodístico. Editor de Bolaño salvaje y Toda la sangre.

Fecha de recepción: 12 de marzo de 2021

Fecha de aceptación definitiva: 3 de junio de 2021 


\title{
Resumen
}

El artículo estudia dos fenómenos distintos pero interrelacionados: por un lado, las metáforas de la desaparición del yo,y, por otro, el mecanismo de la desaparición de la metáfora o de los sentidos metafóricos en la representación de procesos como la desaparición del yo o la abyección del yo. El marco teórico viene fundamentalmente de Kristeva, Blanchot, Agamben, Derrida y Mitchell, y de las teorías de los «inmirable». Los cómics estudiados son Maus y MetaMaus, de Spiegelman; La ciudad ausente, de Scafati y de Santis; Parallel Lives y Arsène Schrauwen, de Olivier Schrauwen, y Body World y New School, de Dash Shaw.

Palabras clave: abyección, Dash Shaw, Luis Scafati, metáfora, Olivier Schrauwen

\begin{abstract}
The present article studies two different but interconnected phenomena-firstly, metaphors of the disappearance of the self, and, secondly, the mechanism of disappearance of metaphors or of metaphorical meanings in the representation of processes like the disappearance of the self or the abjection of the self. The theoretical frame is provided fundamentally by Kristeva, Blanchot, Agamben, Derrida, and Mitchell, as well as by theories of the unwatchable, while examples are drawn from Spiegelman's Maus and MetaMaus, Scafati's and de Santis's La ciudad ausente, Olivier Schrauwen's Parallel Lives and Arsène Schrauwen, and Dash Shaw's Body World and Nerw School.
\end{abstract}

Keywords: abjection, Dash Shaw, Luis Scafati, metaphor, Olivier Schrauwen

\section{Cita bibliográfica}

Faverón Patriau, G. «Lo abyecto y lo inmirable: la muerte de la metáfora en Spiegelman, Scafati, Schrauwen y Shaw», en CuCo, Cuadernos de cómic, n. ${ }^{\circ} 16$ (2021), pp. 64-87. 
En el año 2019, Nicholas Baer, Maggie Hennefeld, Laura Horak y Gunnar Iversen recogieron en un libro - titulado Unwatchable - ${ }^{1}$ textos de medio centenar de filósofos y teóricos literarios y audiovisuales en los que se ofrecen otras tantas concepciones de lo inmirable. ${ }^{2}$ Unos hablan del horror de lo sublime; otros, de imágenes de la tortura o sobre la tortura que implica mirar esas imágenes; otros tocan el tema de la difícil introspección de reconocerse en figuras abominables. Las ideas contrastan, se multiplican y no pocas veces se contradicen. Pero todas parecen coincidir en un punto: conjugan la idea de visión como fenómeno físico y como asunto moral o ético. Abstrayendo las diferencias para fijarnos en las intersecciones, lo inmirable es lo visible que no queremos ver pero vemos de todas maneras, o bien a nuestro pesar, atraídos por la curiosidad de lo atroz, por un vértigo morboso, o bien convocados por una fuerza mística. El espectro es amplísimo: abarca desde el final de la Comedia, cuando Dante imposiblemente trata de ver a Dios, hasta el cine de horror, los videos y foros escondidos en la dark web o el snuff. Lo inmirable es visible y perturbador; posee un atractivo irresistible, nos cuestiona moralmente, aunque a veces, como en el éxtasis místico, puede más bien reconfirmar nuestro sentido moral. Nos centraremos en el polo negativo y en la idea de que también son inmirables las imágenes de lo abyecto, definido en los términos de Kristeva: lo que franquea los lindes del tabú, nos confronta con lo inhumano de lo humano, nos empuja a borrar el límite entre el yo y lo otro, y a reconocernos en eso otro incluso si lo aborrecemos. Kristeva diría, por ejemplo: la visión del cadáver que nos recuerda nuestra muerte, o el regreso de lo reprimido en la culpa original del incesto, en el amor narcisista por la madre - cuando creemos que la madre es todavía parte de uno mismo- o en el ritual asesinato del padre, que nos lleva a un estadio prelingüístico, inexpresable en palabras. ${ }^{3}$

Y dado que lo inmirable en lo que se enfoca este ensayo está relacionado con lo abyecto, y con ese volver a lo prelingüístico, entonces también se relaciona con el vértigo de buscar en el lenguaje lo que no podemos encontrar en él, aquello de lo que hablaba Blanchot en referencia a «El Aleph» de Borges, cuando aludía a la literatura borgeana como una caminata infinita en dirección a los bordes de lo representable, al vértigo que nace de la intención de decir lo inefable —o, en el caso de «El Aleph», decir lo

${ }^{1}$ BaEr, N. et al. (eds.). Unwatchable. New Brunswick, Rutgers UP, 2019.

2 Uso «inmirable» como traducción de unwatchable. De acuerdo con Oxford Languages, el uso de la palabra unwatchable fue poco documentado hasta 1945, cuando se hizo frecuente y entró en la lengua común. Oxford Languages no explica el motivo, pero es posible que fueran dos hechos históricos de 1945, la liberación de los campos de exterminio nazi en Alemania y Europa del Este y los bombardeos nucleares de Hiroshima y Nagasaki, los que, al proveer al mundo con una enorme cantidad de imágenes solo visibles con horror, pusieron la palabra en circulación.

${ }^{3}$ Kristeva, J. Powers of Horror. An Essay on Abjection. New York, Columbia UP, 1981. pp. 4-8. 
que es inefable porque nunca debió ser visto-.${ }^{4}$ Concebidas de ese modo, también serían inmirables las imágenes que representan la disolución del yo, porque ella es una forma de muerte, que nos aproxima a la «abyección del yo» sobre la cual teoriza Kristeva; ${ }^{5}$ y lo deberían ser las imágenes que, al representar, aunque sea de manera metafórica, las cosas que asociamos con la abyección, nos colocan frente a ella.

Sin embargo, parte de este ensayo quiere observar la manera en la que ciertos cómics parecen circunnavegar ese escollo, para presentar ante el lector lo inmirable -incluido lo abyecto. Para hacerlo, partiremos de la idea de que mucho de lo escrito sobre la abyección y sobre lo inmirable, al asentarse fuertemente en la teoría literaria, a pesar de que lo inmirable es por definición un objeto visual, puede y suele pasar por alto, irónicamente, la manera en la que el medio del cómic, que sí es un medio visual, es capaz de hacernos ver lo inmirable, e incluso disfrutarlo visualmente, no regateándonos la culpa de esa abyección, sino colocando el objeto inmirable ante nuestros ojos, antes de que podamos desviar la mirada y antes de que podamos convencernos de haberlo disfrutado. Por supuesto, las artes visuales suelen tener la aspiración de representar en imágenes lo que se supone imposible de ver, tanto lo místico - Dios en los frescos de Michelangelo - como lo físico — por ejemplo, las esferas celestes diseñadas por astrónomos y cartógrafos en el siglo XVII, que acogían el heliocentrismo para dibujar la galaxia mucho antes de que pudiera ser vista- También nos han mostrado, a lo largo de siglos, en la obra de Blake, en la de Goya, en la de Bacon, lo que es inmirable no por invisible sino por abyecto, y el cómic en particular, o al menos las viñetas caricaturescas, eventualmente, lo han hecho, alguna vez, incluso antes que cualquier otra forma de arte visual. Después de los bombardeos atómicos de Hiroshima y Nagasaki, por ejemplo, las primeras representaciones del estallido nuclear no fueron fotografías, sino viñetas de caricaturas de prensa, dado que la publicación de imágenes testimoniales de la destrucción urbana fue prohibida durante meses; los retratos de los sobrevivientes, por siete años, y las filmaciones del hongo nuclear casi no existieron, salvo por una película borrosa, casi ilegible.

Es notorio que esas representaciones, en algunos casos, eludieron precisamente la abyección de la realidad que representaban, pero eran de cualquier forma vehículos de representación, a pesar de su carácter metafórico, elusivo. En ellas existe un intento de comprensión de un fenómeno histórico reciente (las caricaturas incluidas aquí datan de la semana de los bombardeos) y existe un ánimo notorio por colocar ante los ojos del espectador sus dimensiones mundiales, la manera en que compromete no solo la masacre de las ciudades japonesas, sino el futuro de la humanidad en manos de la tecnología y de la ciencia. Esto es especialmente visible en la FIG. 2, donde es un científico quien tiene en sus manos la bomba, el objeto en el que quedan cifradas la vida y la muerte de la humanidad misma, representada por un bebé.

\footnotetext{
${ }^{4}$ Blanchot, M. The Book to Come. Stanford, Stanford University Press, 2003. pp. 93-98.

${ }^{5}$ Kristeva, J. Op. Cit.p. 5.
} 

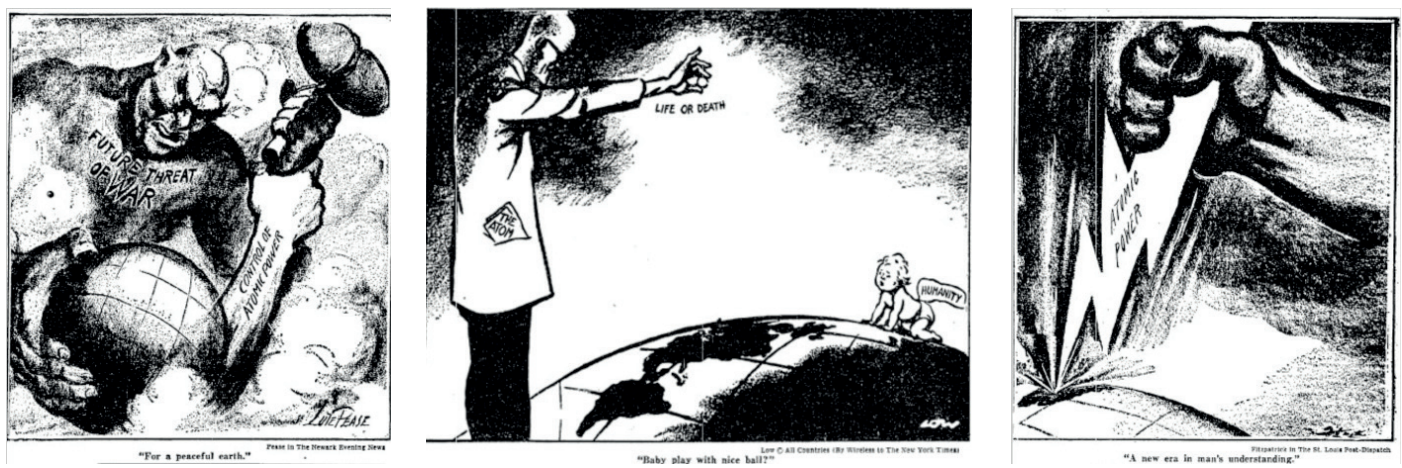

FIG. 1 / FIG. 2 / FIG. 3. todas publicadas el 12 de agosto de 1945 en el New York Times.

Este ensayo estudiará el uso de lo metafórico para colocar visualmente ante el espectador el hecho de la abyección, concentrándose en ciertos vehículos particulares, todos ellos correspondientes a novelas gráficas, algunas canónicas y otras recientes. Su objetivo es mostrar cómo ciertas novelas gráficas han transitado desde ese nivel metafórico, e incluso alegórico, que vemos en las caricaturas de la prensa de 1945, hasta reformulaciones de lo metafórico que parecen, primero, cuestionar su puro «sentido figurado» para acentuar su literalidad, y, luego, colapsarlo en un uso que solo superficialmente parece metafórico pero que, en efecto, implica una superación o una eliminación de la metáfora, que preserva solo lo específicamente literal.

En cierta forma, los primeros pasos de ese proceso podrían explicarse tomando como ejemplo el Maus de Art Spiegelman y las reflexiones, también en forma de cómic, del mismo Spiegelman sobre su obra más célebre, muchos años después de publicada. En Maus, un primer nivel metafórico aparece en la representación de los diversos involucrados en la Shoah como animales de diversas especies: las víctimas judías son ratones, los victimarios nazis son gatos, los colaboracionistas o los simples testigos o los testigos culposos son cerdos. ${ }^{6}$ La metáfora es engañosa, porque parece subdividir lo humano en especies animales para referirse a un tema cuyo origen ideológico, el racismo, es otra forma de deshumanización (FIG. 4). Ya en el mismo Maus, sin embargo, hay por lo menos un personaje que transita ambiguamente hacia adentro y hacia fuera de esa representación por especies: el dibujante mismo - o el personaje que lo representa - es unas veces un ratón y otras veces un ser humano con máscara de ratón, en cierta medida ajeno al universo representado, capaz de entrar y salir de él a través de la memoria de su padre (FIG. 5). ${ }^{7}$ Décadas más tarde, en el 2011, en

\footnotetext{
${ }^{6}$ Spiegelman, A. Maus. New York, Pantheon Books, 1991.

7 Sobre la metáfora animal en Maus y el momento particular en el que el personaje-narrador se quita la mascara, ver Mcglothlin, E. «No Time like the Present: Narrative and Time in Art Spiegelman's Maus?», en Narrative Narrative 11.2 (2003), p. 183. Debe añadirse que el título de la novela, puesto
} 
MetaMaus, Spiegelman es todavía más consciente de ello, y se representa como un ratón solo para de inmediato hacer notar que su rostro es una máscara y arrancarse esa máscara para mostrar el rostro, que es el de una calavera, como si él, o bien hubiera sido una víctima directa del Holocausto, en lugar de una víctima de segunda generación, o bien empezara a concebir su propio lugar en tanto autor del libro como el lugar de la muerte. ${ }^{8} \mathrm{El}$ rostro de ratón, entonces, literalmente enmascara otro que, pese a ser más real, es otra vez metafórico: la calavera, la muerte. Pero esa cancelación de la primera metáfora para reemplazarla por otra no nos aleja de la realidad, sino que nos aproxima más a ella. Nos coloca frente al hecho mismo de la abyección: el hecho de haber estetizado lo que por definición no debería producir placer estético, haber caído en la trampa de ver lo inmirable y haberle tendido la misma trampa al lector. Es un primer paso en el camino a la eliminación de lo metafórico porque aún no alcanza lo literal, sino que anula una metáfora para suplantarla por otra.

Demos un paso atrás, hacia el concepto mismo de lo inmirable. La mayor parte de las explicaciones recientes de esa noción son culturalistas. Aluden a objetos que podemos ver aunque creamos que no deberíamos mirarlos. En un sentido cultural, lo inmirable se define hoy, casi siempre, en función de tabúes sociales. Cada nación, cada cultura, cada sociedad, decide qué es mirable y qué es inmirable (es el mecanismo del tabú). Pero no puede definir culturalmente lo visible y lo invisible, pues estos son fenómenos físicos y no culturales, de manera que lo inmirable, por definición, debe ser antes visible. Meghan Sutherland hace notar que "podemos ver algo, pero rechazamos la posibilidad misma de soportar esa visión, o de sentir una genuina apreciación estética por ese algo» cuando «los protocolos de un sistema de tabúes» declaran que algo no debe ser visto. ${ }^{9}$ Sutherland llega, a partir de eso, a una conclusión interesante: «lo mirable y lo inmirable», afirma, «se vuelven [en un sentido ontológico] indistinguibles uno del otro», porque solo el sistema de tabúes culturales puede diferenciarlos, de manera que la naturaleza de lo inmirable radica más en el sistema cultural que en los objetos en si. $^{10}$ En el caso de Spiegelman, la representación visual de lo abyecto del Holocausto solo pudo ser metafórica en un principio, en los años ochenta, cuando comenzó, en Raw, la publicación periódica de Maus, y eso respondió al tabú, aún existente entonces, de la representación del horror de los campos de exterminio, pero pasadas tres décadas es otra abyección la que lo lleva a otras metáforas: la abyección de haber engendrado un objeto visible de goce estético. Ya cuando la representación del Holocausto ha dejado de

en singular (Maus, en lugar de Mäuser) parece aludir bastante más al narrador-mediador, el personaje hijo del sobreviviente del Holocausto, que a los judíos víctimas de primera generación, dado que es el único que parece ocupar una posición única entre los personajes (los demás, de una forma u otra, pertenecen efectivamente a los colectivos implicados de primera mano en el hecho histórico).

8 Spiegelman, A. MetaMaus. New York, Random House/Pantheon Books, 2011.

9 Sutherland, M. «Pro Forma», en Baer, N. Et Al. (eds.). Unwatchable. New Brunswick, Rutgers UP, 2019, p. 55.

${ }^{10}$ Idem. 
ser tabú en Estados Unidos y en buena parte del mundo, cuando el Holocausto se ha vuelto objeto de otras novelas gráficas y documentales y películas y series de televisión, en el siglo XXI, lo abyecto se desplaza a otro terreno: el del placer estético. O, dicho en otras palabras, el nuevo tabú cultural ya no es la representación misma, sino la abyección de la estetización; esto, que no ven los productores de esas otras novelas gráficas y películas y series televisivas, lo ve Spiegelman y lo muestra, en MetaMaus.
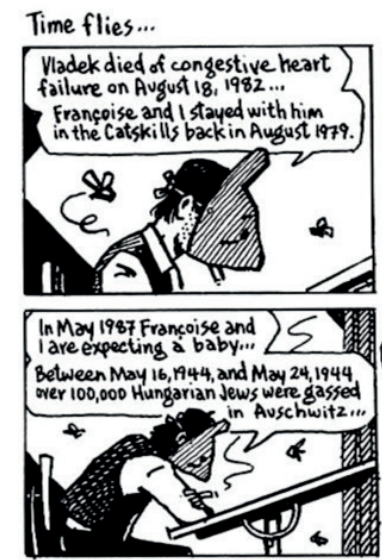
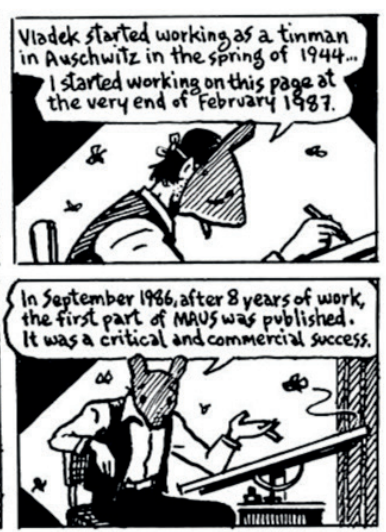

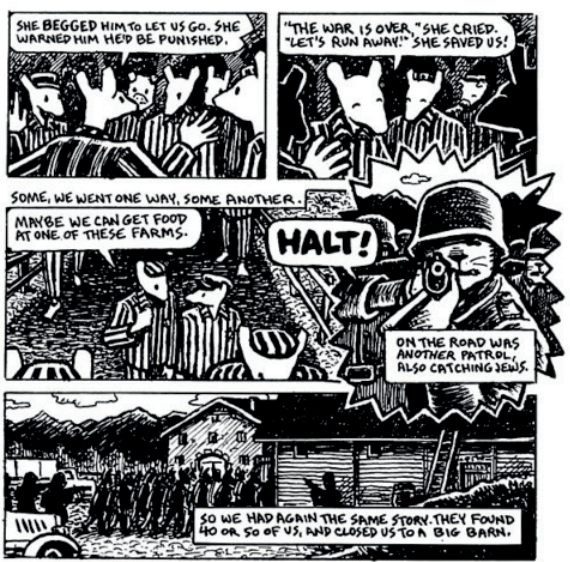

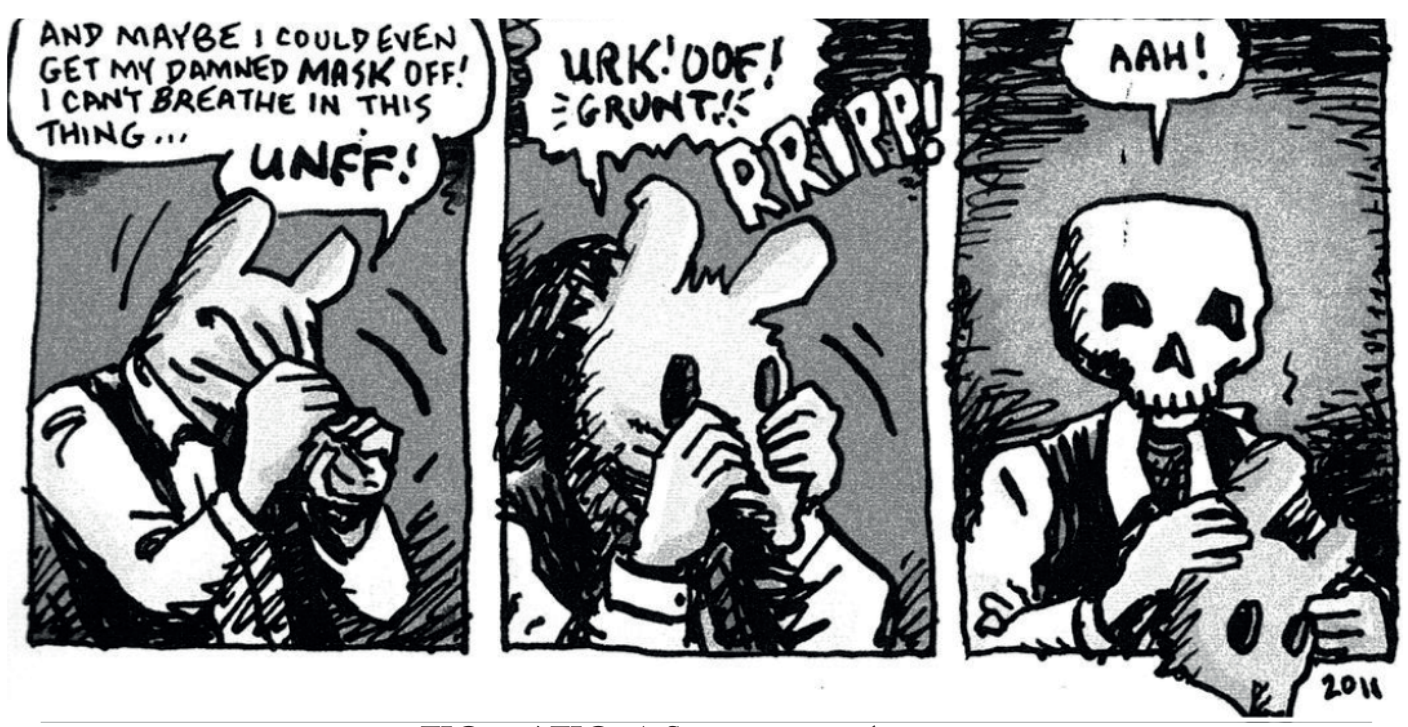

FIG. 4 / FIG. 5. Spiegelman, A. Maus.

New York, Pantheon Books, 1991, pp. 108 y 41. / FIG. 6. Spiegelman, A. MetaMaus. New York, Random House/

Pantheon Books, 2011, p. 9.

Lo que aterra a Spiegelman y lo conduce a la doble metáfora de la máscara que cubre otra máscara, es, además, el horror de haberse colocado en el lugar de la víctima directa - al representarse él mismo como un ratón-. Alenka Zupančič, en un ensayo brillante, alude al tema del Holocausto y de la conversión de ciertos lugares de memoria 
del Holocausto en sitios turísticos. Observa que «la idea de que podamos encontrar [1a] experiencia [de visitar esos lugares] intelectualmente gratificante o interesante o satisfactoria, es una fuente de horror», y subraya que eso es un rasgo inalienable de lo inmirable: la superposición o la fusión de lo horroroso con lo gratificante. ${ }^{11}$ En el centro de esa afirmación de Zupančič está una idea doble, y a primera vista contradictoria - aunque en verdad no es contradictoria sino simplemente dialéctica-. Por un lado, la intuición de que ir a un campo de exterminio, o visitar sus ruinas, nos coloca en el lugar remoto de un espectador del Holocausto: estamos en el sitio, y no somos las víctimas, y si no somos las víctimas debemos ser (somos) parte de un espacio distinto del de las víctimas. Por otro lado, sin embargo, ese espacio distinto debe ser el mismo donde se emplazó la maquinaria aniquilante que causó la victimización: entonces puede ocurrir que nos percibamos como parte del campo de exterminio y, de esa forma, como victimarios. La idea no deja de recordar el dictum de Hegel según el cual el arte no es capaz de mostrar «la verdad» porque el artista (el ser humano en general) está dentro de «la verdad», sin capacidad alguna de asumir una posición subjetiva afuera de ella. ${ }^{12}$ Mutatis mutandi, «la verdad» representada en el campo de concentración, o en sus ruinas, nos incluye de manera tan rigurosa que no encontramos ninguna posición subjetiva en ella, y nos integramos al objeto. En su propio ensayo sobre Auschwitz, Giorgio Agamben ha hecho notar que el centro del problema de la representación del Holocausto es la ausencia necesaria de la víctima final, la ausencia de los testimonios de las víctimas radicales, es decir, no el testimonio de los sobrevivientes (como los padres de Spiegelman) sino la inevitable ausencia de los testimonios de los muertos. Al leer los testimonios de los sobrevivientes, dice Agamben, «se vuelve claro que el testimonio contiene en su centro mismo un vacío esencial». ${ }^{13}$ Ante ese vacío, el observador, ya transformado en parte de la maquinaria del campo de exterminio, como apuntaba Zupančič, se encuentra en otra encrucijada, otra vez dialéctica: la de intentar colocarse a sí mismo en ese centro, llenar ese vacío, cosa imposible, porque se trata de una experiencia no solo no sufrida sino acaso inimaginable.

Estos son casos extremos y este ensayo no quiere lidiar solo con los casos extremos sino también con los que en apariencia son más cotidianos y podríamos haber experimentado nosotros mismos - la abyección nos acompaña, no es insólita, aunque sea aborrecible; lo inmirable, asimismo, nos rodea-. Pero no he aludido a esos otros casos en vano, sino para hacer notar que, ante la alternativa de ser nosotros mismos parte de la maquinaria del campo de aniquilamiento, o intentar llenar el vacío colocándonos en el lugar de la víctima, lo que se opera es una disolución del yo: el yo que o bien no puede o bien no quiere o no busca colocarse en ninguna de esas dos posiciones, $y$ que acaba evaporándose entre una y otra — quizás por eso visitar Auschwitz no es en

11 Zupančič, A. «Melting into Visibility», en Baer, N. et. Al. (eds.). Op. cit., p. 49.

12 Hegel, G. W. F. Lecciones sobre la estética. Madrid, Akal, 1989. p. 14.

13 Agamben, G. Remnants of Auschwitz. The Witness and the Archive. New York, Zone Books, 2018. p. 13. 
sí mismo una experiencia traumática, aunque pueda ser dolorosa: porque sus consecuencias son no solo reprimidas sino suprimidas-. La disolución del yo no necesita de esas situaciones límite: puede operarse en circunstancias menos radicales, ante una crisis psíquica, ante un trauma personal que puede ser o no ser parte de una situación colectiva, incluso ante ciertas formas de duda acerca del lugar de uno mismo en el mundo - lo que solía llamarse una «crisis existencial»-. Un caso interesante, por intermedio, lo encontramos en La ciudad ausente, la novela gráfica de Scafati y De Santis, ${ }^{14}$ basada en la ficción del mismo título de Ricardo Piglia. Es un caso intermedio porque no implica una situación extrema y radical como la del Holocausto, pero sí una crisis política y una dictadura, y las opresiones de la dictadura sobre quienes la sufren y la resisten, incluyendo la violencia psíquica implicada en ello y las formas de disolución del yo que sobrevienen a esa violencia. Tanto la novela de Piglia como la de Scafati y De Santis se emplazan en una suerte de Argentina distópica que vive bajo los rigores de una tiranía omnipresente, un régimen policial que controla incluso los pensamientos y la imaginación de los sujetos y al cual los sujetos responden, a su vez, con diversas formas de imaginación, entre ellas la de proyectar un mundo (de palabras y figuras semihumanas, en Piglia; de imágenes visuales en Scafati y De Santis) que paulatinamente se confunde no solo con el mundo real sino también con el mundo construido por la dictadura. La incertidumbre de lo real conduce al protagonista a disociarse de sí mismo, sospechar de su propia existencia, descreer no solo de lo real exterior sino de su propia realidad, ontológicamente. En la novela de Piglia esto es deslizado en una intrincada red de discursos sobrepuestos, que saltan de un plano a otro de la realidad, o de la irrealidad; en la versión de Scafati y De Santis, el fenómeno no es explicado - pese a que el cómic recoge buena parte del texto de Piglia—, sino fundamentalmente mostrado.

Una vez más, la disolución del yo tiene que ver con la imposible solución ante la interrogante de si el sujeto - Junior, el protagonista - es parte de una maquinaria de la que no quiere sentirse parte o si es una víctima de ella, pero, en este caso, además, la maquinaria es doble: las proyecciones del Estado y las proyecciones de la resistencia. Scafati representa las instancias de la disolución de varias maneras distintas. En la FIG. 7, estamos ante la afirmación de la realidad del yo en medio de un mundo que parece disolverse a su alrededor, con ese personaje central cuya representación linda con el realismo en contraste con el mundo bosquejado en su entorno, hecho de trazos semidisueltos y figuras fantasmales, en unos casos, y, en otros, abiertamente monstruosas o demoniacas. En la FIG. 8, en cambio, el protagonista empieza el camino de inmersión en ese mundo del esbozo y el bosquejo incierto, él en retirada mientras que, a sus espaldas, el sillón queda como una ruina del mundo real, un recordatorio de que tal vez sí existe una realidad tangible, de la que él se aleja. En la FIG. 9, los dos personajes son representados como discursos, cuerpos hechos de palabras, en una viñeta que, además, muestra una escena de carácter sexual, pero que pierde todo posible ero-

${ }^{14}$ Scafati, L. y De Santis, P. La ciudad ausente. Buenos Aires, Océano, 2000. 
tismo y le escamotea toda realidad al yo, al concebirlo como un dudoso producto del lenguaje: una ficción en un mundo que cada vez más se llena de ficciones. Es en esa triple circunstancia — ser parte de la maquinaria, ser producto de la maquinaria, ser víctima de la maquinaria - que el sujeto pierde toda individualidad y se transforma en el ser tres veces escindido de la FIG. 10, que recupera los rasgos que el personaje tenía en un inicio, pero que ya se ha disuelto como individuo: ¿quién de los tres será el yo, cuando el triple personaje enuncie la palabra «yo»?
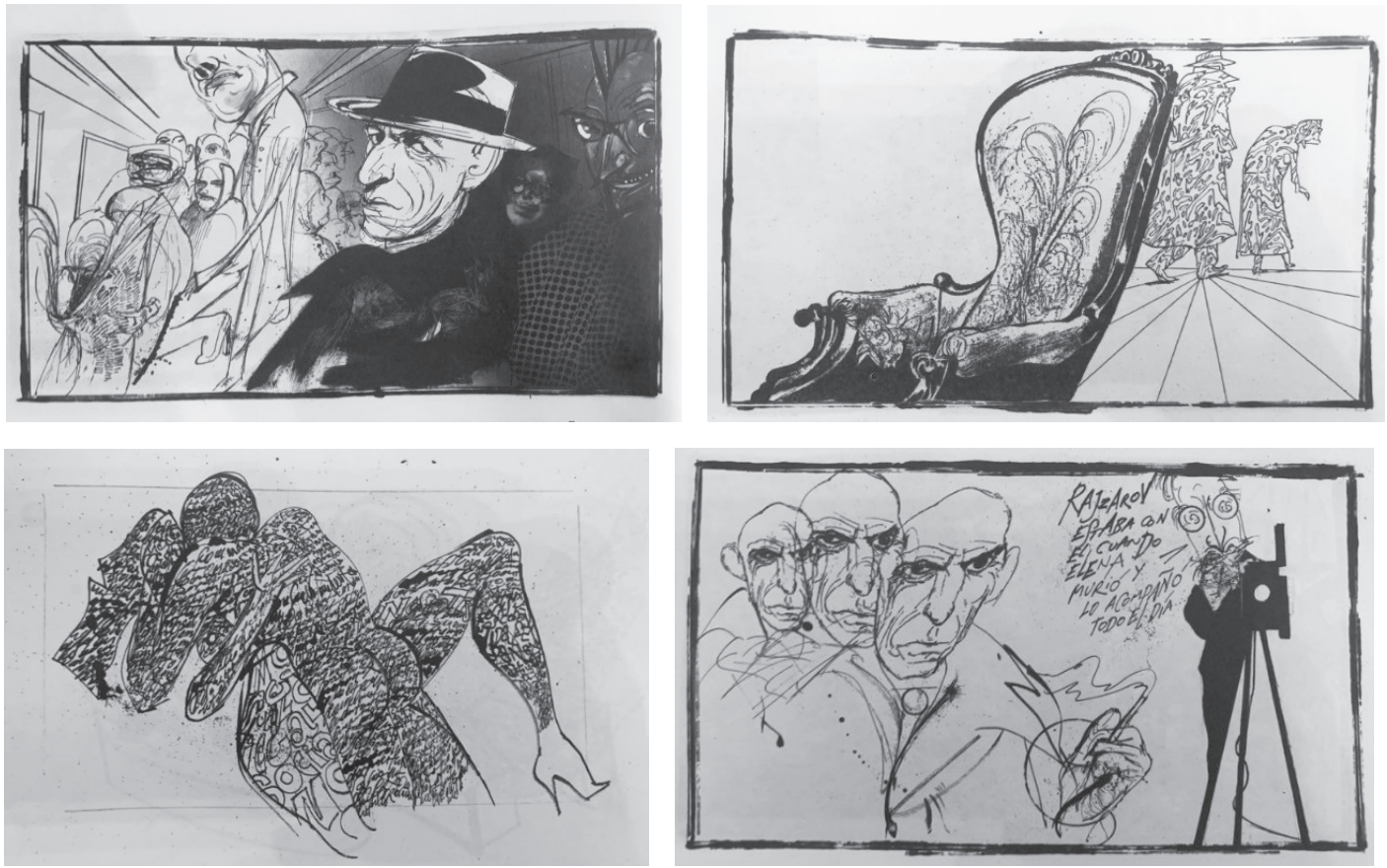

FIG. 7 / FIG. 8 / FIG. 9 / FIG. 10. ScAfati, L. y De Santis, P. La ciudad ausente. Buenos Aires, Océano, 2000, pp. 22, $65,71,85$.

Entonces estamos frente a una de las formas de abyección de las que habla Kristeva, la que ella llama la «abyección del yo», y que, en sus palabras, sería «la forma culminante de esa experiencia del sujeto al cual se le revela que todos los objetos [de su mundo] están basados meramente sobre la pérdida inaugural que trazó los cimientos de su propio ser» ${ }^{15}$ En Kristeva, esa pérdida inaugural es el momento de separación de la madre, seguido por el momento de la canibalización freudiana del padre. En la novela gráfica de Scafati y De Santis, padre y madre son simbólicamente perdidos a la vez, puesto que lo que el individuo pierde en la confusión de su noción de realidad, y en el extravío de su certeza acerca de su propia realidad, es precisamente cualquier idea de origen: su pregunta fundamental no es solo «quién soy yo realmente», sino «de dónde

${ }_{15}$ Kristeva, J. Op. cit. p. 5. 
vengo»; casi literalmente: «de dónde salí». La consecuencia inmediata no puede ser otra que la abyección del yo, la sombra de la idea de que uno mismo es una aberración (un ser sin origen: una suerte de espectro), cuya consecuencia no puede ser otra que la disolución del yo, último refugio ante esa forma «culminante» de abyección.

Pero notemos que todo esto lo figura Scafati sin recurrir a ningún uso metafórico, sino, más bien, todo lo contrario, al deshacerse de la metáfora para mostrar la literalidad de la imagen: si, en la novela de Piglia, el personaje, Junior, tiene la sensación de la incertidumbre, la escisión y la disolvencia, en la novela de Scafati y De Santis, notoriamente debido a la representación visual de Scafati, Junior no siente esas cosas, ni piensa sobre esas cosas, sino que esas cosas le ocurren: la desaparición es la realidad, disparada por la abyección del yo, y eso no solo nos coloca a nosotros ante la visión de lo inmirable, sino también a él, en la penúltima página de la novela, cuando Junior se ve a sí mismo ya disuelto, recuperando su apariencia física, su exterior, pero ya sin ser un yo (FIG. 11).

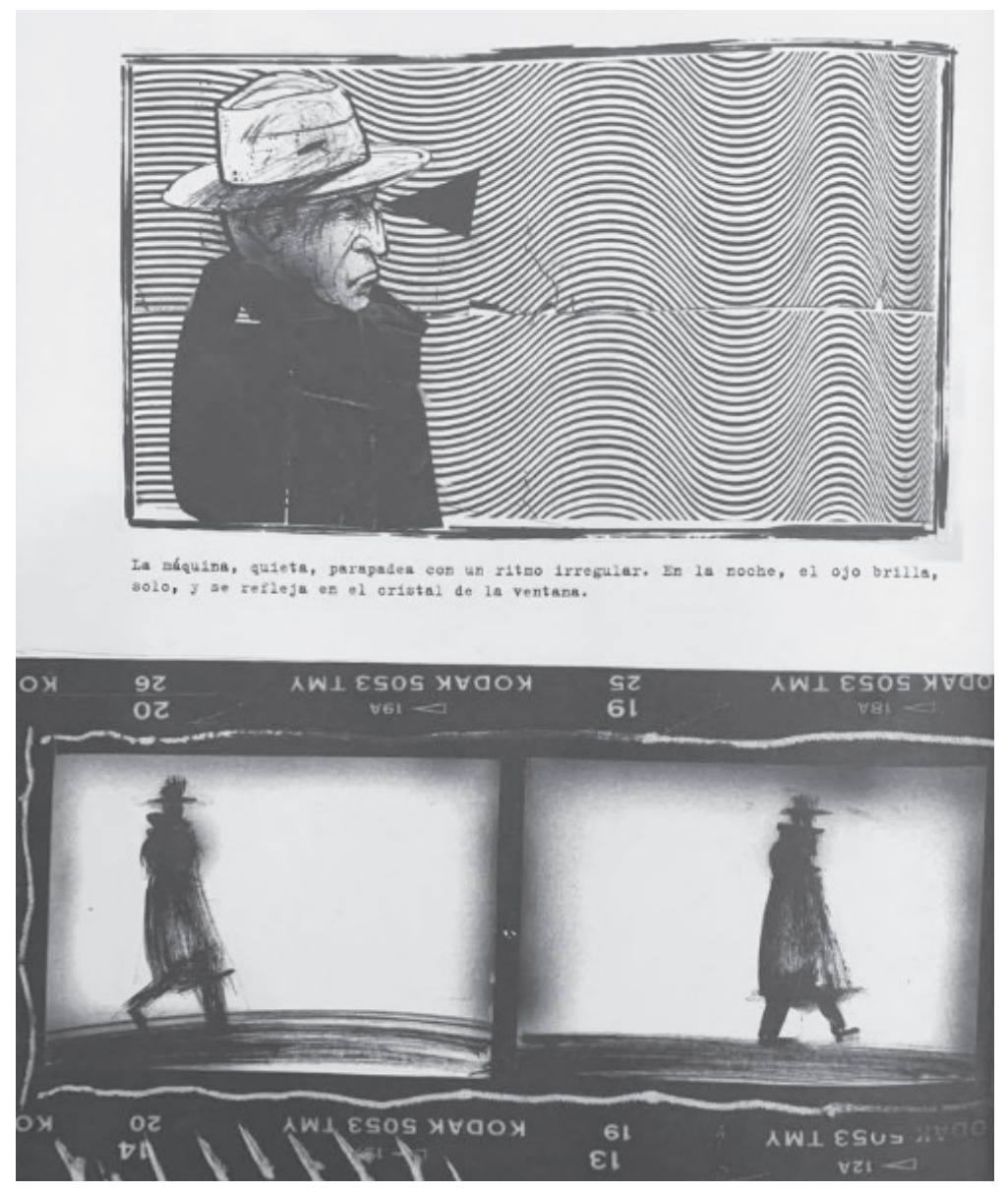

FIG. 11. Scafati, L. y De Santis, P. Op. cit., p. 90. 
¿La eliminación de lo metafórico es una costumbre de la novela gráfica? Quizás no es un hábito muy común pero sí es una forma gráfico-retórica de construir una figura que no está en el vocabulario de la retórica clásica — de donde heredamos el término «metáfora»- y que sí está, en cambio, en el lenguaje del cómic, aunque tal vez no en el lenguaje crítico del cómic. No se trata de no recurrir a metáforas, sino de postular una metáfora para después quitarle su valor metafórico. Puesto de otro modo: si, desde la filosofía del lenguaje, Davidson sostenía que no puede existir una metáfora si no preexiste a ella un sentido literal, que finalmente es el único sentido cierto, algunos autores de cómics - y voy a proponer a Dash Shaw y Olivier Schrauwen entre ellosparecen postular que hay ciertas cosas que solo pueden representarse si son primero mostradas como metáforas para después quitarles el sentido metafórico y devolverlas a una suerte de pura literalidad. ${ }^{16}$ Veamos dos ejemplos evidentes, tomados de la novela Arsène Schrauwen, de Oliver Schrauwen: ${ }^{17}$
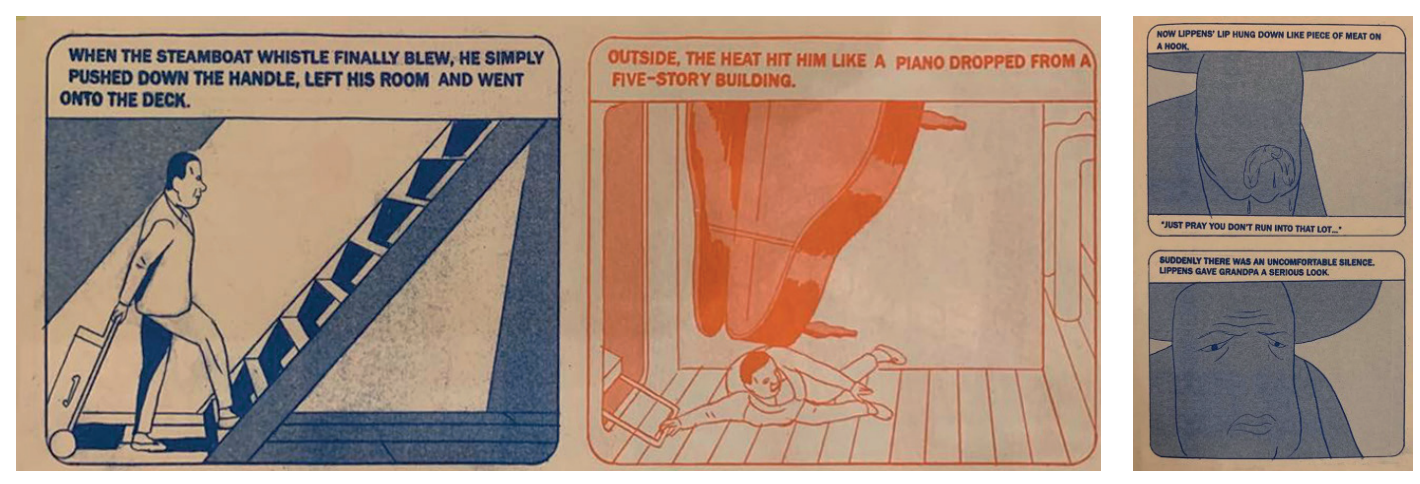

FIG. 12 / FIG. 13. Schrauwen, O. Arsène Schrauwen. Seattle, Fantagraphics, 2014, pp. 17 y 13.

En la FIG. 12, Arsène, el protagonista, presentado como un antepasado del autor, viaja en un barco del que está a punto de descender. No es un viaje cualquiera, sino una migración, un cambio de mundo - es un belga que viaja al Congo-. Al llegar, tiene su primer encuentro con el clima del nuevo país, y la descripción escrita es una metáfora: «el calor lo golpeó como un piano que hubiera sido arrojado sobre él desde un edificio de cinco pisos». Hasta ese punto en la novela, la relación entre los textos $\mathrm{y}$ los dibujos ha sido siempre de una correspondencia literal: las imágenes funcionan como una mera repetición de lo dicho, hasta un punto tal en que el lector puede percibirlos como redundantes, como si las viñetas no hicieran otra cosa que ilustrar el

${ }_{16}$ Davidson era incluso más radical. Su idea completa es que «las metáforas significan lo que las palabras significan en su interpretación más literal, y nada más». Cualquier otra cosa que desprendemos de ellas, asegura Davidson, es una imposición adicional de sentido, ajena a la metáfora misma. Ver: Davidson, D. «What Metaphors Mean», en Critical Inquiry 5.1 (1978), p. 32.

17 Schrauwen, O. Arsène Schrauwen. Seattle, Fantagraphics, 2014. 
texto. Cuando aparece la viñeta roja, eso se repite: la imagen reproduce literalmente lo que dice el texto, pero esta vez el texto ha sido metafórico, y la imagen parece no comprender la metáfora, de manera que, en lugar de representar a un hombre sofocado por el calor, representa a un hombre literalmente aplastado por el piano. En ese momento, paradójicamente, cuando el lector comprende que los dos discursos, el textual y el gráfico, van a seguir correspondiéndose uno al otro, comprende también que, en lo fundamental, no se corresponden, puesto que en uno (el escrito) existe la metáfora, mientras que en el otro solo existe el primer momento de construcción de la metáfora, que es, siempre siguiendo a Davidson, exclusiva y necesariamente literal. La FIG. 13 ofrece otro ejemplo pertinente. Son dos viñetas: en la primera se repite el fenómeno, cuando el texto dice "Ahora el labio de Lippens colgaba como un pedazo de carne de un gancho», mientras que el dibujo, en lugar de mostrar un gesto adusto o un gesto de tristeza, muestra un pedazo de carne que cuelga de un gancho: esta vez no ha sido una metáfora, sino un símil, pero la anulación del sentido figurado del tropo a favor de la persistencia de (o el regreso a) lo literal es la misma. ${ }^{18}$. Anotemos, porque será relevante luego, que en esas dos imágenes ocurre otra cosa interesante: el personaje no tiene ojos cuando se habla de sus labios, y recobra los ojos cuando se describe su mirada. Parece un rasgo de economía gráfica, una suerte de minimalismo, pero en verdad corresponde a una constante en Schrauwen: momentos en que parece producirse una imposibilidad de percibir los rostros completos, las identidades completas, como si los personajes estuvieran siempre a punto de disolverse.

Volveremos a Schrauwen luego; pero antes veamos una imagen de la novela Bottomless Belly Button, de Dash Shaw, en la que se reúnen esto último, la pura literalidad de lo metafórico, que parece anular la metáfora, con lo que veníamos explorando antes: la disolución del yo. ${ }^{19}$ Bottomless Belly Button es una novela gráfica de argumento muy complejo, a pesar de que toda ella ocurre en un solo fin de semana en el que los hijos de un matrimonio de ancianos se reúnen en una casa de playa a visitar a sus padres que acaban de anunciarles su inminente divorcio. Aunque cada uno de los hijos se vuelve alternativamente protagónico, no es exagerado decir que uno de ellos, Peter, es el personaje central. Peter es también el único que no es representado como un ser humano: tiene el cuerpo de un hombre joven pero el rostro de una rana o de algo muy semejante a una rana. El lector se lleva una impresión semejante a la que siente ante los personajes animalizados de Maus, pero a lo largo de los cientos de páginas (no numeradas) de la novela, se pregunta por

18 Bill Kartalopoulos ha hecho notar la costumbre de Schrauwen de seguir las premisas de la seudociencia fisiognómica del siglo XIX — que atribuye rasgos de personalidad a los individuos a partir de los rasgos de su rostro, un poco a la manera lombrosiana de clasificar personalidades según la forma del cráneo-, solamente para subvertirlos. Desde mi punto de vista es más que una pequeña rebelión anacrónica contra la frenología: es una exacerbación irónica de sus principios, en la que la carencia de rasgos implica la carencia de identidad. Ver: Kartalopoulos, B. «Olivier Schrauwen and the Physiognomy of Style», en World Literature Today 89.2 (2015), p. 11.

19 Shaw, D. Bottomless Belly Button. Seattle, Fantagraphics, 2008. 
qué solo ocurre eso con Peter. Únicamente pasados dos tercios del libro, y solamente en una imagen, el rostro de Peter se transforma:

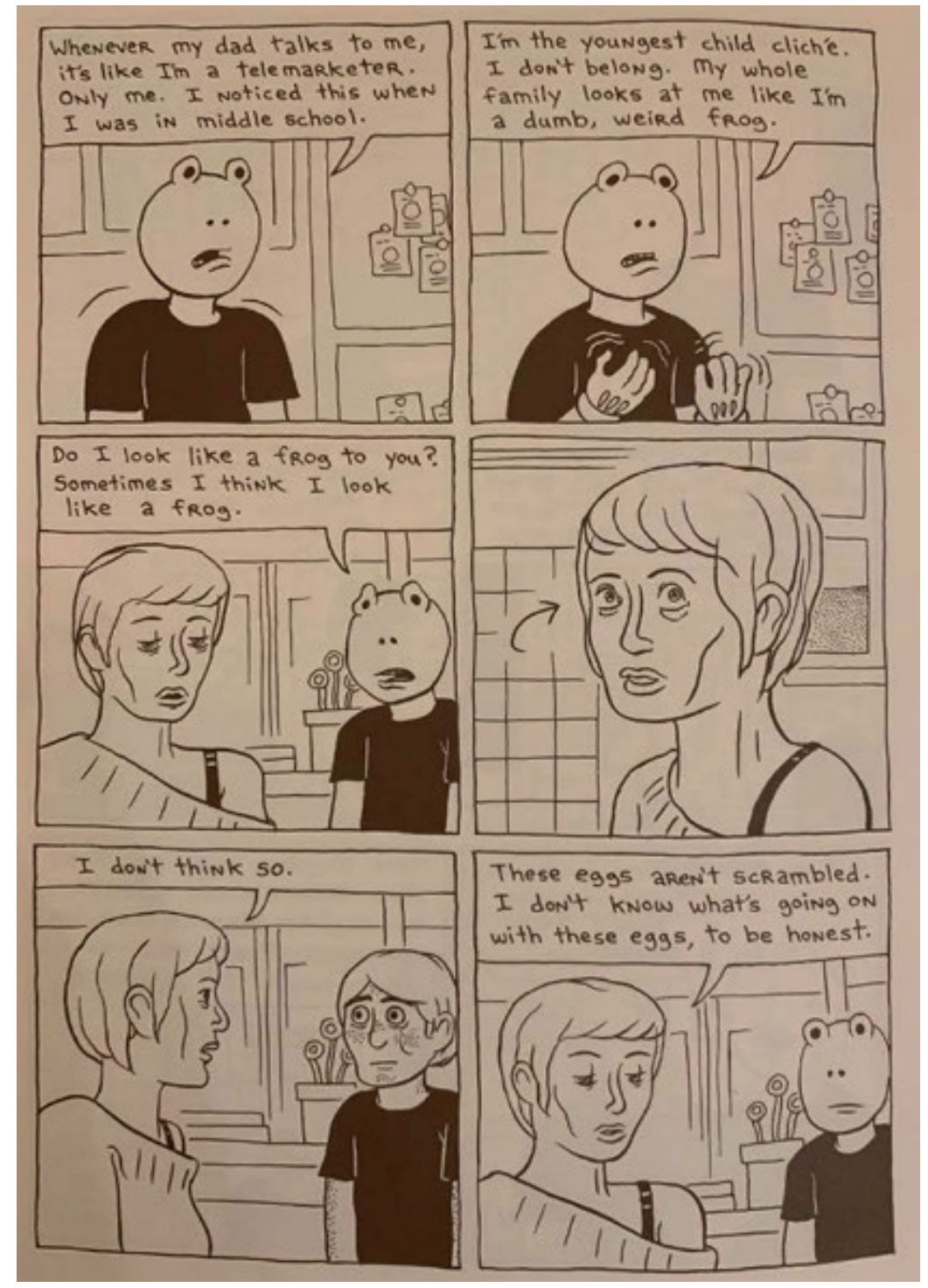

FIG. 14. Shaw, D. Bottomless Belly But-

ton. Seattle, Fantagraphics, 2008, s.p.

Muestro aquí (FIG. 14) la página completa para que el lector tenga una idea de cuál es la apariencia de Peter en todo el resto de la novela y también de cuán fugaz es el instante en que vemos su rostro humano. Ocurre en la quinta de las seis viñetas de esa página, y no vuelve a suceder nunca más. En la segunda viñeta de la misma página aparece el único diálogo en el que Peter toca el tema de su apariencia: «Toda mi familia me mira como si fuera una rana idiota y extraña». Luego, en la tercera viñeta, le pregunta a la chica — a la que acaba de conocer y de la que se está enamoran- 
do- si en verdad parece una rana. En la cuarta viñeta una flecha que señala los ojos de ella nos indica que lo que viene será lo que ella ve, y en la quinta es donde aparece el rostro humano de Peter. En la sexta ella se da vuelta y él otra vez luce como una rana, y se quedará con ese rostro hasta el final de la novela — un par de cientos de páginas más-. Entendemos que hay algo semejante a una metáfora en la representación de Peter como una rana, pero también entendemos - como cuando Spiegelman se quita la máscara- que no es una metáfora propiamente, sino un ocultamiento, y sabemos, además, que es una autopercepción: es Peter quien se ve de esa forma y su punto de vista — que él cree que corresponde a la mirada de sus padreses el que ha dominado, entonces, todos los momentos de la novela en los que él aparece. Digo que no es una metáfora propiamente porque otra vez es, más bien, un síntoma, el del desprecio por sí mismo, la abyección del yo, la figuración de la persona como un ser aberrante para sí misma, motivada por un desconcierto ante el propio origen - como decía Kristeva, como ocurre con Junior en La ciudad ausente-: no en vano toda la historia en la que Peter se ve como una rana coincide con los días en los que su padre y su madre deciden disolver su matrimonio, rompiendo con eso la familia y dejando a Peter, el menor de sus hijos, el único que aún no es propiamente un adulto, por primera vez, en la coyuntura de enfrentarse al mundo tras haberse roto, por decirlo así, el cordón umbilical que lo tenía hasta entonces unido a sus padres, a su origen.
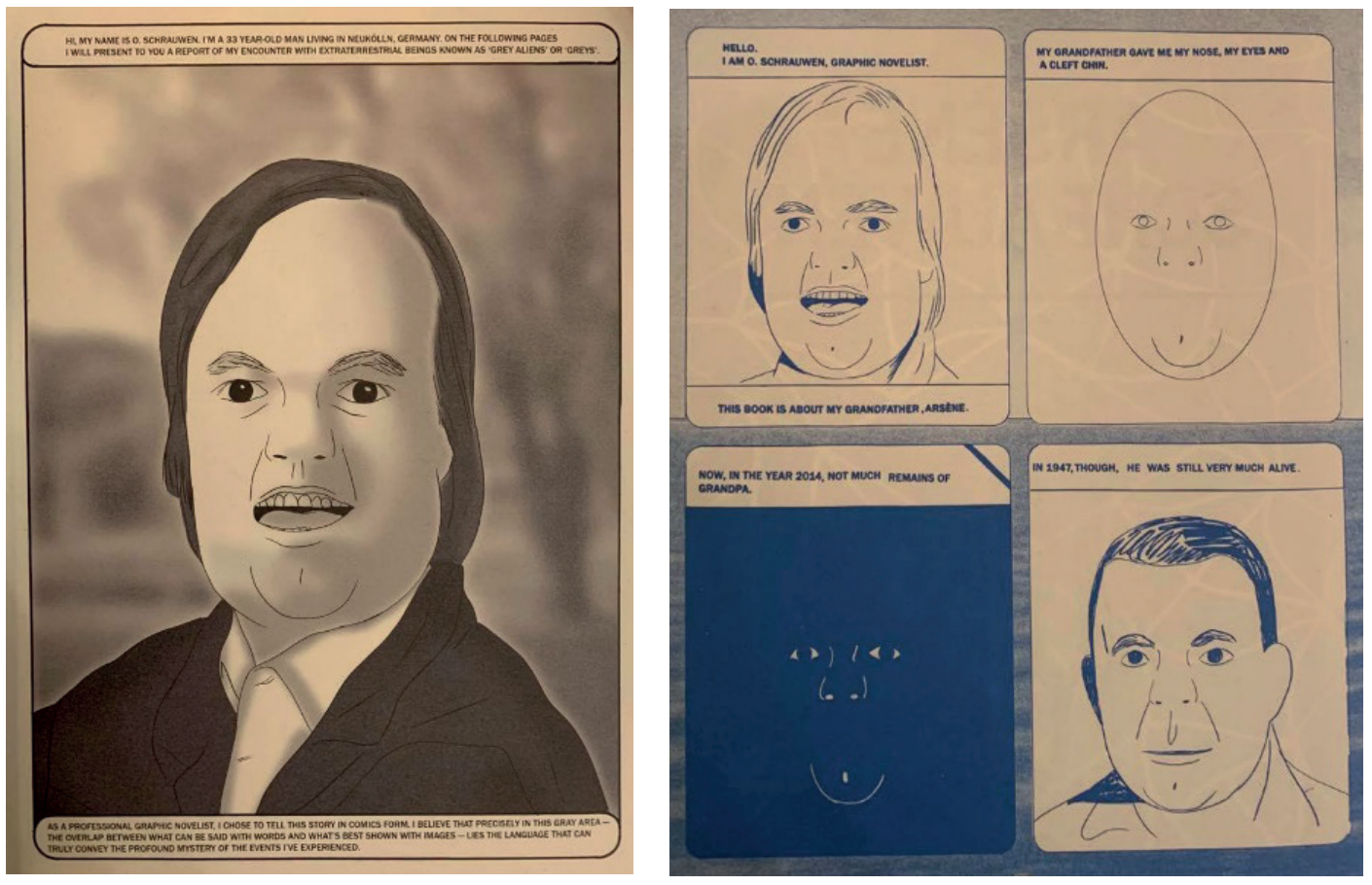

FIG. 15. Schrauwen, O. Parallel Lives.

Seattle, Fantagraphics, 2018, p. 5. / FIG.

16. Schrauwen, O. (2014). Op. cit., p. 4. 
También en los libros de Olivier Schrauwen las vinculaciones y desvinculaciones de la familia inciden en la autorrepresentación de los personajes, y en su disolución, principalmente cuando se trata de los personajes que se presentan con el nombre del autor. En Parallel Lives, ${ }^{20}$ la novela se abre con lo que a todas luces es un autorretrato, acompañado por dos textos que no dejan lugar a duda, donde el personaje se identifica con el nombre del autor y se declara «un novelista gráfico profesional», aunque a medida en que el relato avance ese rostro se irá deformando y convirtiendo en muchos otros, según la historia devenga cada vez más fantástica y alucinatoria (FIG.15).

Pero los lectores de Schrauwen saben que esa imagen, o una casi idéntica, ya alguna vez apareció en la primera página de otra novela suya, Arsène Schrauwen, de la que hablamos antes — sobre los ejemplos de lo antimetafórico-, y saben que, en esa novela anterior, esa imagen en particular es el inicio de una secuencia de desaparición del yo, una en la que el personaje pierde sus rasgos humanos para convertirse, primero, en una especie de esquema de sí mismo, después en una serie de rasgos perdidos en una oscuridad azul, para solo reintegrarse ya transformado en su abuelo, Arsène (FIG. 16). Es necesario notar que el salto en el tiempo de principios del siglo xxI a mediados de los años cuarenta, es de dos generaciones, de Olivier a Arsène, de modo que los dos cuadros en los que el rostro desaparece, y con él el yo, son los que corresponden a la generación intermedia: el yo desaparece, literalmente, con la desaparición del padre, que en este caso es retóricamente una elipsis, pero que no puede ser sino una alusión a la quebrazón del vínculo entre padre e hijo.

Es en esos momentos de abandono, de desvinculación afectiva, tanto en Schrauwen como en Dash Shaw, que los personajes parecen desconfigurarse, disolverse, hasta que encuentran un salvavidas del cual cogerse - el recuerdo del abuelo en Schrauwen-, o una mirada que les devuelva la humanidad - la mirada de la chica enamorada en Shaw-. Una instancia notable de ambas cosas aparece en la misma Arsène Schrauwen, en relación con el romance de dos personajes secundarios, uno de ellos un empresario delirante, con sueños de grandeza, inventor de mundos artificiales, y el otro un socio suyo, que, como la rana humanoide de Shaw, es el único personaje de la novela de Schrauwen que no tiene un rostro humano más o menos realista, sino que es representado como un esquema primario, un círculo con un par de rasgos que aparecen y desaparecen de manera más o menos azarosa, a veces unos anteojos, a veces un bigote, a veces solo unas líneas de cabello, que permiten suponer que es una persona, pero no más. Así como Peter, en Bottomless Belly Button, de Dash Shaw, recupera su rostro humano una sola vez, visto por la mujer, así este personaje de Schrauwen se transforma súbitamente en una persona completa cuando recibe las caricias de su amante (FIG. 17).

$\overline{{ }^{20} \text { Schrauwen, O }}$. Parallel Lives. Seattle, Fantagraphics, 2018. 


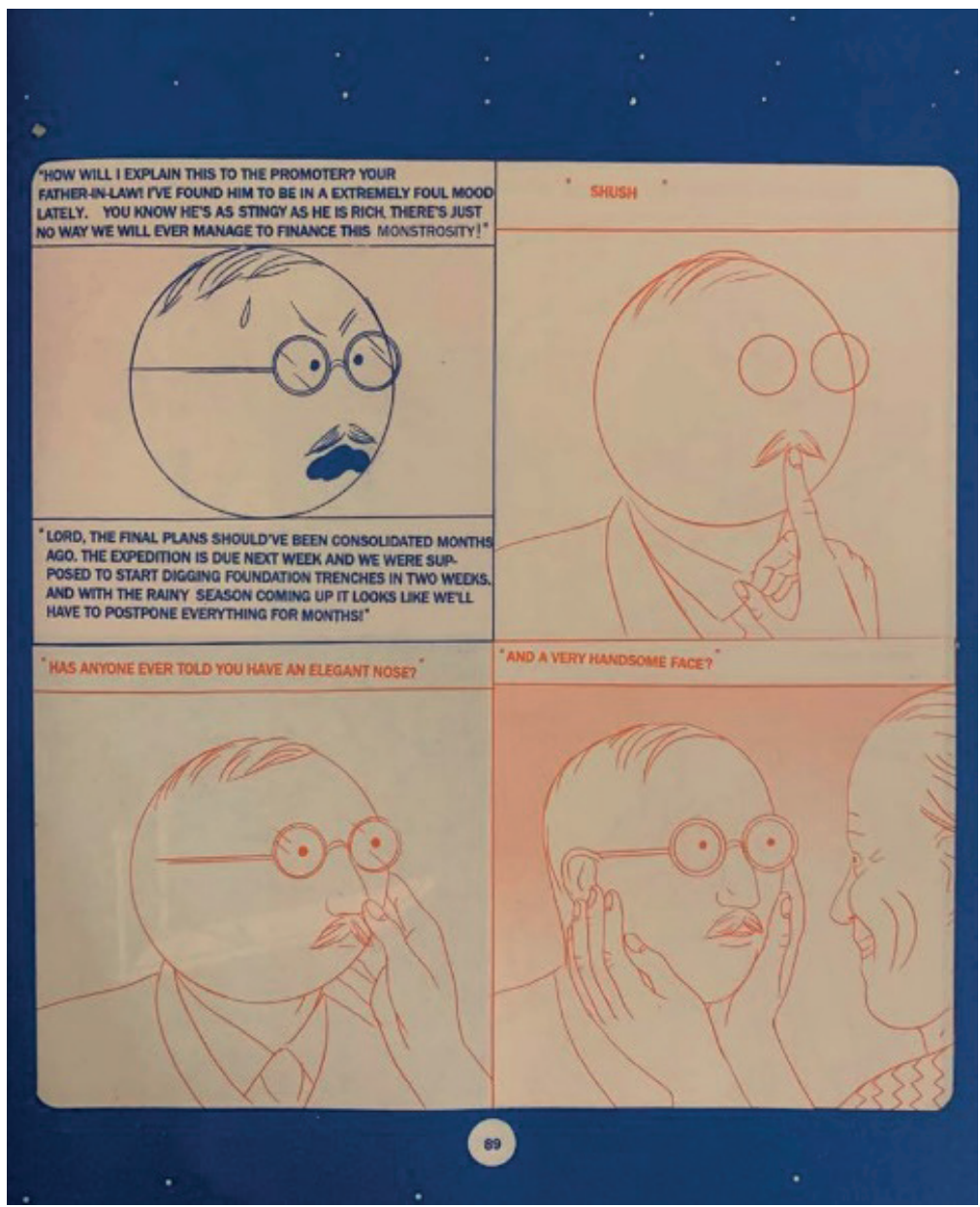

FIG. 17. Schrauwen, O. (2014). Op. cit., p. 89.

Solo en ese instante se nos revela que es un personaje al que nunca hemos visto como es, sino solamente como él se percibe a sí mismo, con una suerte de autodesprecio, pero, significativamente, también descubrimos que no era un afán metafórico el que animaba esa representación esquemática, sino que era el producto literal de su percepción: para sí mismo, él no es humano, hasta que el reconocimiento del otro lo humaniza. Dije líneas arriba que, en las ficciones de Schrauwen, intermitentemente, parece emerger la imposibilidad de percibir los rostros completos, las identidades completas, como si los personajes estuvieran a un paso de deshacerse en la nada: este es otro caso, uno en el cual el personaje se salva de la desaparición del yo debido a la mirada afectiva del otro, que lo rescata de esa aberración que es la abyección del yo (en este caso un odio por sí mismo producto de la naturaleza clandestina de su amor homosexual, pero que cesa precisamente en el momento en que ese amor se puede permitir dejar el secreto, con la única persona con la que puede hacerlo). 
En Shaw, por su parte, existe otra forma de disolución del yo que también está relacionada con la abyección y lo inmirable, y que Shaw representa en por lo menos dos novelas, Body World y New School. La primera, Body World, es la historia de un hombre, especialista en probar plantas alucinógenas para reportar sobre ellas a una institución que las investiga, un hombre que hace tiempo ha perdido cualquier idea de moral o de ética, y cualquier forma de conexión afectiva con el mundo, y que un día descubre y prueba una planta dejada en la tierra por una avanzada civilización extraterrestre. ${ }^{21} \mathrm{El}$ efecto de la planta es confundir las personalidades e incluso los cuerpos de dos personas que estén físicamente próximas la una a la otra cuando la consumen. New School, por su parte, cuenta la historia de dos hermanos que van a vivir en un lugar extraño, una isla gobernada por un científico que está efectivamente creando un mundo artificial dentro de ella, de modo que a los habitantes de la isla, incluidos los dos hermanos, se les hace poco a poco imposible diferenciar las fantasías del mundo inventado por el científico de las cosas que son parte del mundo real —una situación no del todo distinta de la que vive Junior en La ciudad ausente-. En esta última, Nerw School, la indecisión entre lo real y lo imaginado, proyectado o simplemente inventado y sobrepuesto al mundo, conduce a los hermanos a un estado de desdoblamiento perpetuo, que nunca es reconocido en los diálogos, pero que el lector infiere de las imágenes. ${ }^{22}$
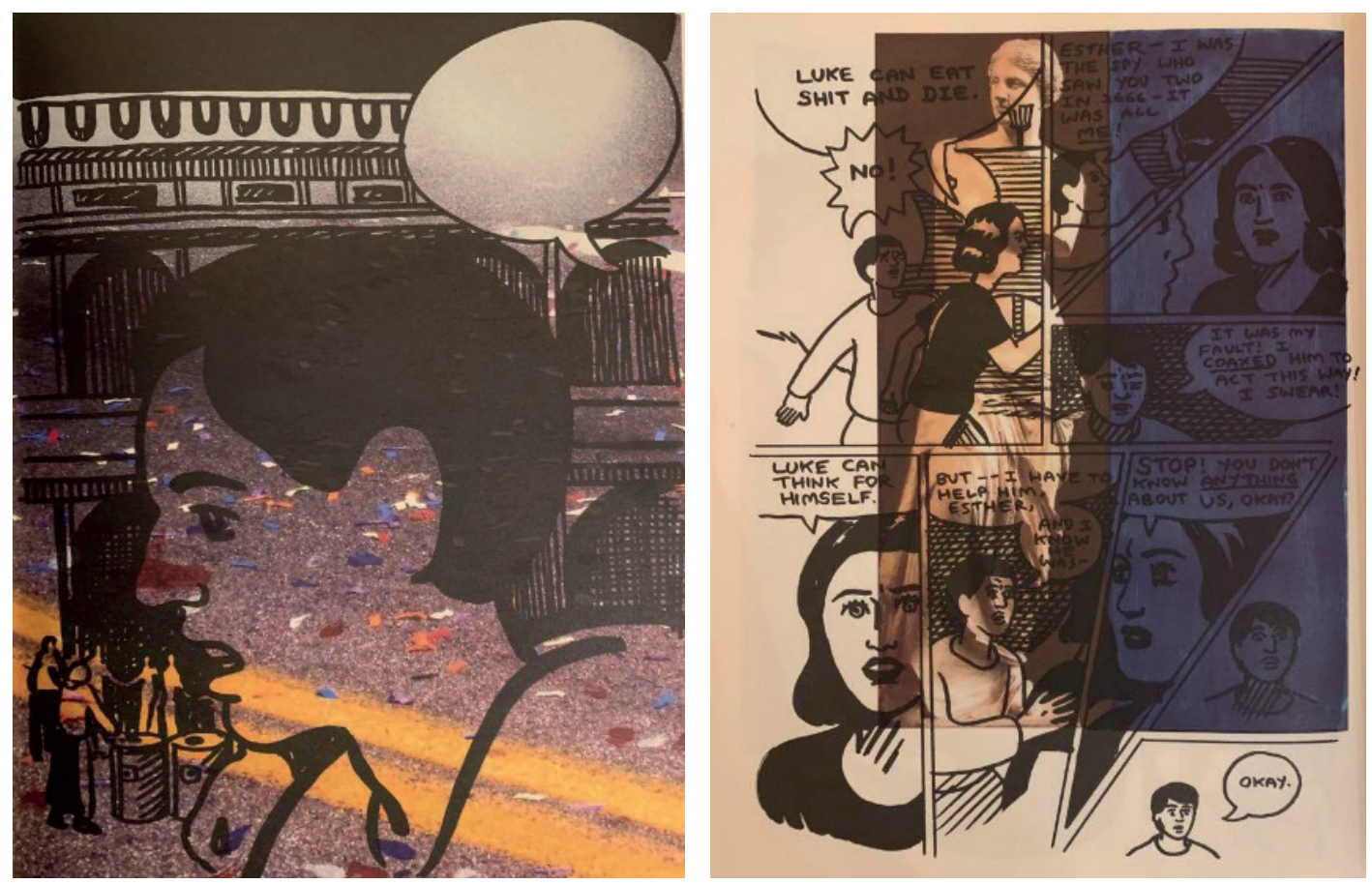

FIG. 18 / FIG. 19. Shaw, D. New School.

Seattle, Fantagraphics, 2013, s.p.

${ }^{21}$ Shaw, D. Body World. New York, Pantheon Books, 2010.

22 Shaw, D. New School. Seattle, Fantagraphics, 2013. 
En unos casos, como en la FIG. 18, se trata simplemente de la sobreimpresión del rostro de uno de los hermanos sobre el desolado paisaje de la feria, también llamada New School, que contiene los inventos del científico - y que sin duda recuerda las descripciones de Disneyland que formula Jean Baudrillard en Simulacra and Simulations - ${ }^{23}$ Pero la imagen claramente alude también a la manera en que ese medio irreal penetra al sujeto, dejándolo en un limbo entre la realidad y la ficción, la realidad y la irrealidad o la realidad y el simulacro, pero sobre todo en un limbo entre su entero reconocimiento de sí mismo como la persona que ha sido hasta entonces y la persona en la que se está transformando al abandonar la realidad - y una vez más, todo esto ocurre la primera vez en que el personaje y su hermano abandonan la casa familiar y rompen el lazo con sus padres-. En la FIG. 19 vemos el otro mecanismo, más típico del estilo gráfico de Shaw, que consiste en construir una página de manera más o menos convencional, para luego romperla con la interferencia de grandes manchas de color que no corresponden al orden de las viñetas, sino que les imponen un orden ajeno, distinto, de manera tal que el lector intuye que, incluso cuando los personajes creen estar viviendo en un solo mundo - en un solo relato, en una sola secuencia-, más o menos estable y más o menos confiable, en verdad están no solo divididos entre varios mundos, sino atravesados por diversos mundos. O quizás sea mejor decirlo en el orden inverso: los diversos mundos que habitan simultáneamente los acaban fragmentando, de modo que los sujetos pierden su carácter de individuos para volverse esquirlas de individuos: una vez más, la disolución del yo.
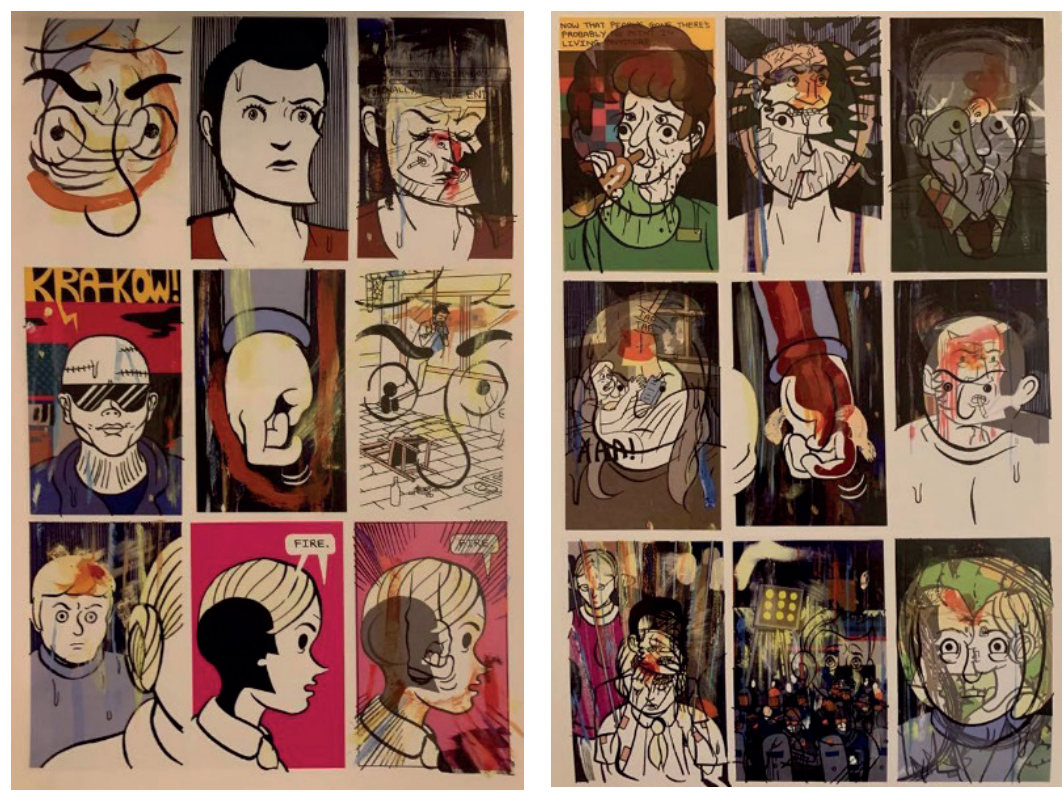

FIG. 20 / FIG. 21. Shaw, D. Body World.

New York, Pantheon Books, 2010, s.p.

23 «Disneyland se presenta como imaginario para hacernos creer que el resto [del mundo] es real». Ver: Baudrillard, J. Simulacra and Simulations. Ann Arbor, University of Michigan Press, 1994. p. 5. 
En Body World, por su parte, el personaje - el profesional de los alucinógenos, drogadicto de oficio- provoca involuntariamente una suerte de plaga. Inconsciente de que el efecto de la droga alienígena que ha hallado es introducir en una persona los rasgos de cualquier otra que esté próxima a la primera cuando la consume, rasgos tanto físicos como psíquicos, acaba por hacer víctima del consumo de esa sustancia a buena parte de los habitantes de un pueblo. Pero el verdadero problema - por decirlo así- no es ese, sino que, dado que el primero en consumir la droga ha sido él, y él es un sujeto, como dije, amoral, aborrecible, con tendencias psicopáticas, cuyos mayores indicios de humanidad parecen ser su deseo sexual irrefrenable, casi siempre resulto en onanismo, y su afán autodestructivo — ambos actos solitarios, propios de su naturaleza sociopática-, todos esos rasgos se van contagiando a los demás habitantes del pueblo.

En las FIG. 20 y 21 vemos una de las secuencias en las que ese proceso se pone en marcha: cada personaje es muchos personajes a la vez, cada uno de ellos parece contener a otros dos o tres. Quizá las dos imágenes más escalofriantes para el lector sean la octava y la novena viñetas de la FIG. 20, donde uno ve a la chica, que hasta entonces ha sido el signo de la virtud en la historia, y dentro de ella ve, en negro, el perfil del protagonista, el sociópata, el psicópata, que empieza a adueñarse de su mente — de manera involuntaria para ambos- ${ }^{24}$ Esa imagen bien podría ser una representación visual y metafórica de la simple influencia que una persona oprobiosa puede ejercer sobre una persona inocente, pero en la novela gráfica de Shaw no es una metáfora y, esencialmente, no representa una simple influencia, sino una simbiosis, y, de manera más atroz, como en todos los demás cuadros de esas dos páginas, es una imagen de lo inmirable: la introducción (literal) de la abyección en la mente de una persona. Es algo más: es también lo que Jacques Derrida llamaría una imagen «del orden de lo visible invisible». Dice Derrida, en The Gift of Death:

Si escondo un arsenal nuclear en un silo subterráneo, o... escondo parte de mi cuerpo bajo mi ropa... cualquiera cosa que uno disimula de esta manera se vuelve invisible pero permanece dentro del orden de la visibilidad; sigue siendo constitutivamente visible. De la misma manera pero de acuerdo con una estructura distinta, de todo aquello que llamamos órganos interiores del cuerpo — mi corazón, mis riñones, mi sangre, mi cerebro - decimos naturalmente que son invisibles, pero aún son del orden de la visibilidad: una operación o un accidente pueden exponerlos y traerlos a la superficie; su interioridad es provisional y traer su invisibilidad a la vista es algo que puede ser propuesto o prometido. $^{25}$

${ }^{24}$ Otros comentaristas más optimistas de Body World ven en esto la construcción de una suerte de «caldo de cultivo de una consciencia colectiva». Me resulta una lectura injustificada dado el tipo de cualidad que se transmiten los personajes unos a otros: es cierto que hay una consciencia compartida y ramificante, pero se parece más a una infección que a una conciencia colectiva en cualquiera de sus acepciones usuales. Ver: Gossetr, G. «Body World», en World Literature Today 84.5 (2010), p. 63.

${ }^{25}$ Derrida, J. The Gift of Death. Chicago, University of Chicago Press, 2007. p. 90. 
Finalmente, lo que Dash Shaw muestra en esas imágenes - y lo mismo podemos afirmar de las que hemos visto de Scafati y Schrauwen- es eso que Derrida llama lo visible invisible: lo que no debería ser visto y que solo un evento violento, físicamente violento en Body World, psíquicamente violento en Nerw School y en Scafati y Schrauwen, coloca ante nuestros ojos: lo que debería permanecer oculto pero se ofrece de pronto ante nuestra mirada, y que una vez allí, una vez que su potencial visibilidad se vuelve acto, se transforma súbitamente en inmirable. No por casualidad, en Shaw, esas imágenes cobran un aire espectral. En una conversación con Bernard Stiegler, en 1996, el mismo Derrida se acerca a la idea de lo espectral en relación con lo abyecto y lo inmirable, esta vez hablando acerca de la transformación que la ciencia ha operado en nuestra manera de percibir el mundo, por un lado en referencia a la tecnología médica y por otro en referencia a la tecnología mediática:

Así como la posibilidad de las radiografías, los escáners, los trasplantes, cambia nuestro cuerpo y nuestra relación con él, el espacio de los medios [audiovisuales], no importa si somos espectadores o actores, de una manera u otra, implica una profunda transformación del cuerpo y de nuestra relación con nuestro propio cuerpo. ${ }^{26}$

Las imágenes de Shaw, ciertamente, tienen esa cualidad espectral de la que hablé antes, pero también son producto de ese cambio de percepción que nos permite ver el cuerpo desde su interior, ver lo visible invisible, solo que Shaw lo conduce del campo de los rayos equis y los escáners (o los accidentes y las operaciones) al campo del espíritu y la psique, sin abandonar lo somático, y ve a las personas como fantasmas de sí mismos. Resulta casi perturbador, en este punto, recordar la manera en que W.J.T. Mitchell describe las imágenes del orden de lo fantasmático. Son, dice:

[S]utiles pero no obstante substanciales, imágenes propagadas por objetos que impresionan nuestros sentidos a la fuerza. Hay quien las considera entidades meramente formales, sin substancia, propagadas a través de un medio inmaterial. $Y$ algunas teorías incluso describen la transmisión como una que se mueve en la otra dirección, de nuestros ojos a los objetos. $^{27}$

Resulta perturbador, digo, porque cuando Mitchell describe lo fantasmático, asemeja las imágenes espectrales con las imágenes ocasionadas en la mente como consecuencia de un trauma - -propagadas por objetos que impresionan nuestros sentidos a la fuerza»- y además sugiere que son imágenes colocadas en el mundo por nuestra mirada, como si el objeto revivido en la imagen fantasmal fuera engendrado por «nuestros ojos».

26 Derrida, J. y Stiegler, B. Echographies of Television. Cambridge, Polity Press, 2007. pp. 96.

${ }^{27}$ Mitchell, W. J. T. Iconology. Image, Text, Ideology. Chicago, University of Chicago Press, 1986. p. 11. 
Eso es precisamente lo que hacen Scafati, Schrauwen y Shaw: sus imágenes son como señales visuales que parecen espectros pero que a su vez nos piden proyectar espectros sobre ellas: más que representar lo inmirable o lo abyecto, lo invocan, y nosotros completamos la operación. Nosotros llenamos, con nuestra mirada, ese «vacío esencial» del que hablaba Agamben, que jamás podríamos completar con metáforas. A fin y al cabo, ¿qué es — si no invitarnos a ejecutar esa operación - lo que hace Spiegelman, en el 2011, en MetaMaus, reflexionando sobre Maus, cuando se arranca la máscara y nos deja ver, detrás de ella, su propio fantasma, su propia muerte? Ciertas novelas gráficas han estado colocando lo inmirable ante nuestros ojos desde muchos años antes de que la teoría acuñara el término, y nosotros lo hemos estado viendo, quizás sin saberlo. 


\section{BibLIOGRAFÍA}

Agamben, G. Remnants of Auschwitz. The Witness and the Archive. New York, Zone Books, 2018.

BAER, N. et al. (eds.). Unwatchable. New Brunswick, Rutgers UP, 2019.

Baudrillard, J. Simulacra and Simulations. Ann Arbor, University of Michigan Press, 1994.

Blanchot, M. The Book to Come. Stanford, Stanford University Press, 2003.

Davidson, D. «What Metaphors Mean», en Critical Inquiry 5.1 (1978), pp. 31-47.

Derrida, J. The Gift of Death. Chicago, University of Chicago Press, 2007.

—y Stiegler, B. Echographies of Television. Cambridge, Polity Press, 2007.

Gossetт, G. «Body World», en World Literature Today 84.5 (2010). pp. 63-64.

Hegel, G. W. F. Lecciones sobre la estética. Madrid, Akal, 1989.

Kartalopoulos, B. «Olivier Schrauwen and the Physiognomy of Style», en World Literature Today 89.2 (2015).

Kristeva, J. Powers of Horror. An Essay on Abjection. New York, Columbia UP, 1981.

McGlothlin, E. «No Time like the Present: Narrative and Time in Art Spiegelman’s Maus?» Narrative Narrative 11.2 (2003). pp. 177-198.

Mitchell, W. J. T. Iconology. Image, Text, Ideology. Chicago, University of Chicago Press, 1986.

Scafati, L. y De Santis, P. La ciudad ausente. Buenos Aires, Océano, 2000.

Schrauwen, O. Arsène Schrauwen. Seattle, Fantagraphics, 2014.

_Parallel Lives. Seattle, Fantagraphics, 2018. 
Shaw, D. Bottomless Belly Button. Seattle, Fantagraphics, 2008.

—Body World. New York, Pantheon Books, 2010.

—Nerw School. Seattle, Fantagraphics, 2013.

Spiegelman, A. Maus. New York, Pantheon Books, 1991.

—MetaMaus. New York, Random House/Pantheon Books, 2011.

Sutherland, M. «Pro Forma», en Baer, N. et al. (eds.). Unwatchable. New Brunswick, Rutgers UP, 2019, pp. 52-57.

Zupančıč, A. «Melting into Visibility», en Baer, N. et. Al. (eds.). Unwatchable. New Brunswick, Rutgers UP, 2019. pp. 48-52. 